\title{
Political Parties and Good Governance: Bangladesh Perspective
}

\author{
Md. Rajib Hasnat Shakil ${ }^{1}$, Kaniz Marzia ${ }^{2}$
}

\begin{abstract}
Political parties are mere agents of the people through which the people can organize themselves. They therefore play the function of providing an organizational vehicle for the people. And because, as we pointed out in "Reflections on the three institutions of organized society, Law and government that man chose to move out of solitude in to a life of organized society as a means of enabling him to properly manage the resources and share them equitably, political parties as a vehicle through which the people can organize themselves must be viewed from this perspective of good governance.
\end{abstract}

Keywords: Institution, good governance, democracy, accountability, consensus, politics, election

\section{Introduction}

The strengthening of democracy requires more than well functioning elections, parliaments, an independent judiciary and other institutions and processes. It also requires a strong culture of democracy with robust, transparent, internally democratic and accountable political parties. Political parties represent a key feature of democratic good governance. They provide a structure for political participation which serves as a training ground for future political leaders and to run the government in future winning the national elections. Political parties exist to transform aggregated social interests into public policy inside or outside of the government. To ensure public demand political parties play an important role in shaping the relationship between the executive and the legislature and in prioritizing the legislative agenda. Deepening democratic governance in a Fragmented World, emphasizes, "A well-functioning democracy depends on well-functioning political parties responsive to people ${ }^{3 \%}$.

\section{Good Governance}

Governance describes "the process of decision-making and the process by which decisions are implemented or not implemented ${ }^{4 ،}$. The concept of "good governance" often emerges as a model to compare ineffective economies or political bodies with viable economies and political bodies 5 .

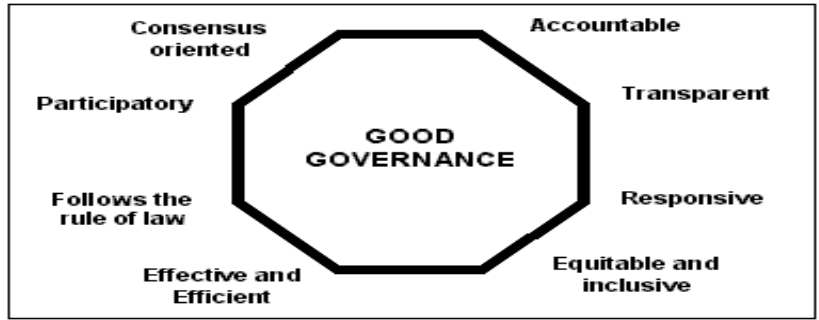

Figure: Characteristics of good governance ${ }^{6}$

\section{Key Elements of Good Governance}

The key elements of good governance as defined by UNDP are listed below ${ }^{7}$ :

\begin{tabular}{|l|l|}
\hline Participation & $\begin{array}{l}\text { Participation by both men and women is a key cornerstone of good governance. } \\
\text { All men and women should have a voice in decision-making either directly or } \\
\text { through legitimate intermediate institutions that represent their interests. Such } \\
\text { broad participation is built on freedom of association and speech, as well as } \\
\text { capacities to participate constructively. }\end{array}$ \\
\hline
\end{tabular}

\footnotetext{
${ }^{1}$ Senior Lecturer, Department of Law, Northern University Bangladesh

${ }^{2}$ BSS \& MSS, Department of Political Science, University of Dhaka, Bangladesh

${ }^{3}$ The 2002 Human Development Report,

${ }^{4}$ What is Good Governance? UNESCAP 2009. Accessed July 10, 2009

${ }^{5}$ Khan, Mushtaq Husain (2004). State formation in Palestine: viability and governance during a social transformation: Volume 2 of Political economy of the Middle East and North Africa.

${ }^{6}$ Ade. (UNESCAP 2009)

${ }^{7}$ UNDP
} 


\begin{tabular}{|c|l|}
\hline Rule of Law & $\begin{array}{l}\text { Legal frameworks should be fair and enforced impartially, particularly the laws on } \\
\text { human rights }\end{array}$ \\
\hline Transparency & $\begin{array}{l}\text { Transparency is built on the free flow of information. Processes, institutions and } \\
\text { information are directly accessible to those concerned with them, and enough } \\
\text { information is provided to understand and monitor them. }\end{array}$ \\
\hline Responsiveness & $\begin{array}{l}\text { Good governance requires that institutions and processes try to serve all } \\
\text { stakeholders within a reasonable timeframe. }\end{array}$ \\
\hline Consensus Orientation & $\begin{array}{l}\text { There are several actors and as many view points the whole community and how } \\
\text { this can be achieved. }\end{array}$ \\
\hline Equity & $\begin{array}{l}\text { All men and women have opportunities to improve or maintain } \\
\text { their well-being. }\end{array}$ \\
\hline Efficiency & $\begin{array}{l}\text { Good governance means that processes and institutions produce results that meet } \\
\text { the needs of society while making the best use of resources at their disposal. }\end{array}$ \\
\hline Vision & $\begin{array}{l}\text { Leaders and the public have a broad and long-term perspective on good } \\
\text { governance and human development, along with a sense of what is needed for } \\
\text { such development. There is also an understanding of the historical, cultural and } \\
\text { social complexities in which that perspective is grounded }{ }^{8} \text {." [6] }\end{array}$ \\
\hline
\end{tabular}

\section{Political parties}

The party system is based on political groups with their own policies, which compete for the support of the people to win power. In Parliament, the two parties with the most Members of Parliament (MPs) form the government and the opposition. A political party is an organized group of people who have similar ideas about how the country should run. Their aim is to get their candidates elected to political power. After a general election, the party with the most MPs usually forms the new government. The second largest party becomes the official opposition, with its own leader and 'shadow cabinet'. Most candidates in elections, and almost all winning candidates, belong to one of the main parties. If an MP doesn't have a political party, they are known as 'Independent'. Activities of the members of political parties lead governance structure of any country why this is one of the most important vehicle of democracy on the way of having good governance.

\section{Political Party and Good Governance}

Political Historical Background of Bangladesh: Bangladesh is a densely populated country in South Asia. Roughly $60 \%$ of its population lives under the poverty level. Its geography is dominated by its low-lying riparian aspect and its population is largely Muslim. History of the role of the political parties to established good governance is rich in Bangladesh, example 1947, 1971, and 1990. Anti-colonial movements against British rule, Pakistani exploitation, militant anarchy. However, these are the single side of the reality. In recent times the ideological conflict between ruling party and the party in opposition is leading the country toward an unwanted situation which will ultimately eliminate good governance segment by segment by poisoning slowly. Most disturbing fact is that political leaders are unwilling to recognize how their actions are threatening the very fabric of democracy. The failure of the political parties to negotiate in keeping national interest threatens the future of democracy in Bangladesh. No doubt, nothing has changed since these remarks were made. In the years since independence, Bangladesh has established a reputation as a largely moderate and democratic majority Muslim country. But this status has been under threat for series of political violence, weak governance, poverty, corruption, and religious militancy. In more recent years religious and anti-religious thoughts have been vigorously pursued by the government. The Bangladesh Nationalist Party (BNP) is led by former Prime Minister Khaleda Zia and the Awami League (AL) is led by current Prime Minister Sheikh Hasina who traditionally have been dominating politics in Bangladesh. AL now is the party in power. Opposition parties always seek to regain control of the government through Hartals (strike), demonstrations, labor strikes, transport blockades and different forms of political turmoil. Political violence has long been part of the political landscape in Bangladesh. In 2007-2008 Bangladesh was ruled by a military-backed caretaker government led by Fakhruddin Ahmed for approximately two years prior to the return to democracy when the political parties of this country were failed to negotiate for the national interest in 2006. It is not so easy to ensure good governance on democratic platform with unstable political atmosphere and now it is great challenge for Bangladesh to combat against transitional haphazard disturbed governance system.

\section{Political parties in Bangladesh}

Bangladesh has mostly a fading two-party system, which means that there are two dominant political parties, with extreme difficulty for anybody to achieve electoral success under the banner of another party. But

\footnotetext{
${ }^{8}$ ADB, Governance in Asia: From Crisis to Opportunity, Asian Development Bank, 1998
} 
currently both are heading coalitions of like-minded parties with the AL leading the secular while BNP is rallying the right-of-centre parties.

VII. Parliamentary parties

\begin{tabular}{|c|c|c|c|}
\hline Bangladesh Awami League & June 23,1949 & $\begin{array}{l}\text { Bangladesh Nationalist } \\
\text { Party (BNP) (Bangladesh } \\
\text { Jatiyatabadi Dal) }\end{array}$ & 1978, Begum Khaleda Zia \\
\hline Bangladesh Jamaat-e-Islami & $\begin{array}{l}\text { 1976, Matiur Rahman } \\
\text { Nizami }\end{array}$ & $\begin{array}{l}\text { Bangladesh Jatiya Party- } \\
\text { BJP }\end{array}$ & $\begin{array}{l}\text { Andaleeve Rahman Partho, } \\
\text { splinter-group of the } \\
\text { original Jatiya Party }\end{array}$ \\
\hline $\begin{array}{l}\text { Communist Party of } \\
\text { Bangladesh }\end{array}$ & $\begin{array}{l}\text { 1968, Manzurul Ahsan } \\
\text { Khan }\end{array}$ & $\begin{array}{l}\text { Socialist Party of } \\
\text { Bangladesh (SPB) }\end{array}$ & $\begin{array}{l}7 \text { November 1980, } \\
\text { Khalequzzaman }\end{array}$ \\
\hline Khilafat Majlis & 1989 & Liberal Democratic Party & $\begin{array}{l}\text { October 26, 2006, . Dr. A. } \\
\text { Q. M. Badruddoza } \\
\text { Chowdhury }\end{array}$ \\
\hline $\begin{array}{l}\text { Islamic Unity Front (Islami } \\
\text { Oikya Jote) }\end{array}$ & & $\begin{array}{l}\text { Islami Oikya Jote (En. } \\
\text { Islamic National Unity } \\
\text { Front) }\end{array}$ & \\
\hline $\begin{array}{l}\text { Jatiya Party - Hussain } \\
\text { Muhammad Ershad (En. } \\
\text { National Party) }\end{array}$ & Hussain Muhammad Ershad & $\begin{array}{l}\text { Jatiyo Shomajtantrik Dal- } \\
\text { JSD }\end{array}$ & \\
\hline Jatiyo Shomajtantrik Dal & $\begin{array}{l}\text { Hasanul Haq Inu Founded } \\
1972\end{array}$ & $\begin{array}{l}\text { Bangladesh National } \\
\text { Awami Party (Bangladesh } \\
\text { NAP) }\end{array}$ & \\
\hline $\begin{array}{l}\text { National Party (Manju) } \\
\text { (Jatiya Dal (Manju)) }\end{array}$ & Abdur Rahim & $\begin{array}{l}\text { Peasants' and Workers' } \\
\text { People's League (Krishak } \\
\text { Sramik Janata League) }\end{array}$ & Bangbir Kader Siddique \\
\hline $\begin{array}{l}\text { Gonotantry Party } \\
\text { (President: Mohammad } \\
\text { Afzal, General Secretary: } \\
\text { Nurur Rahman Salim) }\end{array}$ & & $\begin{array}{l}\text { Islami Andolaon } \\
\text { Bangladesh }\end{array}$ & \\
\hline $\begin{array}{l}\text { Bangladesh democratic } \\
\text { party }\end{array}$ & & $\begin{array}{l}\text { Bangladesh Representative } \\
\text { Party (BRP) }\end{array}$ & \\
\hline $\begin{array}{l}\text { Bangladesh Janata Party } \\
\text { (BJP) }\end{array}$ & & Bikolpo Dhara Bangladesh & $\begin{array}{l}\text { Dr. A. Q. M. Badruddoza } \\
\text { Chowdhury Founded March } \\
2004\end{array}$ \\
\hline
\end{tabular}

VIII. Base of Political party in Bangladesh

Political parties in Bangladesh being formed and are emerging like mushrooms. Here political parties are formed on basis of different ideology; for example, there are fundamental Islamic parties, moderate Islamic parties, Anti Islamic parties, left-wing and right-wing parties, students-affiliated organizations, nationalist Parties and so on. There are even the same-ideological parties; for example, there are six Islamic parties, 16 left/right-wing parties, six nationalist (Jatiyo) parties. It is a clear and somber sign of immaturity and division of the political parties. We, the common citizens of Bangladesh, feel embarrassed and puzzled by so many political parties and creating difficulties become agnostic in decision-making on the choice among the parties which leads misrule and instability.

\section{Political party in Constitution}

The Bangladesh Constitution interprets a "political party" as: "Political party includes a group or combination of persons who operate within or outside Parliament under a distinctive name and who hold themselves out for purpose of prorogating a political opinion or engaging in any other political activity" ${ }^{9}$. Basically political parties are the vehicles by which peoples come together freely to campaign for public office to win a majority of seats in a legislative body, to express their own interests and needs as well as their aspirations for the society in which they live in forming government.

\section{Role of Political party}

Political parties in most of the countries play a vital role in a sustainable and well-functioning democracy to ensure good governance. They generally perform some key tasks:

- Transfer public opinion from citizens to government;

- To pressurize the government to ensure public manifesto;

- Playing a major role in political elections at local and national levels, and ${ }^{10}$

- Creating public feelings giving them different hopes to ensure social and economic stability;

${ }^{9}$ Constitution of Bangladesh

${ }^{10}$ Institutionalization of Democracy in the Political Parties in Bangladesh, Md. Saidur Rahman 
- Aggregating and articulating needs and problems as identified by members and supporters ${ }^{11}$;

- Political education to voters and citizens in the functioning of the political and electoral system and the generation of general political values ${ }^{12}$;

- Include and consider public views into general policies;

- Respecting opposition parties' demands and converting them into general policies ${ }^{13}$;

- Strengthening power of local government to ensure good governance.

XI. Election Result: Party Performance

In Bangladesh political parties have made successful and unsuccessful election and played role in politics

\begin{tabular}{|c|c|c|c|c|c|c|c|c|c|}
\hline $\begin{array}{l}\text { Date of } \\
\text { Election }\end{array}$ & 07-03-73 & $18-02-79$ & $07-05-86$ & 03-03-88 & $27-02-91$ & $15-02-96$ & $12-06-96$ & 01-10-01 & 2008 \\
\hline $\begin{array}{l}\text { Political } \\
\text { parties }\end{array}$ & 14 & 29 & 28 & 08 & 75 & 43 & 81 & 54 & 32 \\
\hline $\begin{array}{l}\text { Total } \\
\text { competitor }\end{array}$ & 1089 & 2125 & 1527 & 977 & 2787 & 1450 & 2574 & 1,935 & 1,538 \\
\hline $\begin{array}{l}\text { Vote } \\
\text { cast }\end{array}$ & 54.91 & $50.94 \%$ & $61.07 \%$ & $57.90 \%$ & $55.45 \%$ & $20.97 \%$ & $74.96 \%$ & $75.59 \%$ & 80 \\
\hline $\begin{array}{l}\text { Women } \\
\text { seats }\end{array}$ & 15 & 30 & 30 & 30 & 30 & 30 & 30 & $30 / 45$ & \\
\hline Result & $\begin{array}{l}\text { AL:29 } \\
\text { Others:7 }\end{array}$ & $\begin{array}{l}\text { BNP:20 } \\
7 \\
\text { AL:39 } \\
\text { Indepen } \\
\text { dent:16 } \\
\text { Others: } \\
38\end{array}$ & $\begin{array}{l}\text { AL:76 } \\
\text { Jamat:1 } \\
0 \\
\text { Indpt:3 } \\
2 \\
\text { Others: } \\
29\end{array}$ & $\begin{array}{l}\text { JP;251 } \\
\text { Indpt:2 } \\
5 \\
\text { Others: } \\
24\end{array}$ & $\begin{array}{l}\text { BNP:14 } \\
0 \\
\text { AL: } 88 \\
\text { Jamat: } 1 \\
8 \\
\text { Others: } \\
19\end{array}$ & $\begin{array}{l}\text { BNP:27 } \\
8 \\
\text { Othrs:1 } \\
1\end{array}$ & $\begin{array}{l}\text { AL:146 } \\
\text { Bnp:11 } \\
6 \\
\text { JP:32 } \\
\text { Others: } \\
6\end{array}$ & $\begin{array}{l}\text { BNP:19 } \\
3 \\
\mathrm{Al}: 62\end{array}$ & AL:230 \\
\hline \multicolumn{10}{|c|}{ Party performance of Bangladesh Election ${ }^{14}$} \\
\hline
\end{tabular}

After losing a majority of seats, all the parties always had alleged that election irregularities were to be blamed. They alleged that their supporters were kept from voting and their polling agents and officials were barred from performing their duties.

Summary of the 9th Bangladeshi National election ${ }^{15}$

\begin{tabular}{|c|c|c|c|c|c|}
\hline Alliance & Party & Votes & $\%$ & Seats & Change \\
\hline \multirow{5}{*}{$\begin{array}{l}\text { Grand } \\
\text { Alliance }\end{array}$} & Bangladesh Awami League & $33,887,451$ & $49.0 \%$ & 230 & +168 \\
\hline & Jatiya Party & $4,867,377$ & $7.0 \%$ & 27 & +16 \\
\hline & Jatiyo Samajtantrik Dal & 429,773 & $0.6 \%$ & 3 & +2 \\
\hline & Workers Party of Bangladesh & 214,440 & $0.3 \%$ & 2 & +1 \\
\hline & Liberal Democratic Party & 161,372 & $0.2 \%$ & 1 & \pm 0 \\
\hline \multirow{4}{*}{$\begin{array}{l}\text { Four } \\
\text { Party } \\
\text { Alliance }\end{array}$} & Bangladesh Nationalist Party & $22,963,836$ & $33.2 \%$ & 30 & -163 \\
\hline & Jamaat-e-Islami Bangladesh & $3,186,384$ & $4.6 \%$ & 2 & -15 \\
\hline & Bangladesh Jatiya Party-BJP & 95,158 & $0.1 \%$ & 1 & -4 \\
\hline & Islami Oikya Jote & - & - & - & - \\
\hline \multicolumn{2}{|c|}{ Independents and others } & $3,366,858$ & $4.9 \%$ & 4 & -2 \\
\hline \multicolumn{2}{|l|}{ Total } & $69,172,649$ & $99.99 \%$ & 300 & \\
\hline
\end{tabular}

XII. Relationship among party leaders

\footnotetext{
11 supra

12 ibid

${ }^{13}$ ibid

${ }^{14}$ Bangladesh Political Science Review,Vol-1,No-1,June-2011

${ }^{15}$ Bangladesh Election Commission
} 
The relation between the powerful moneyed people and the political parties is evident in the Bangladesh political culture in recent times. In election times the party centers deny those grassroots leaders who are politically renowned figures and nominate those with money and power in exchange of huge donations to the parties "Political intrusion, criminalization and immorality have deeply affected the good governance and causes injuries deep into the heart of politics. Political patronage has paved ways for further corruption and malpractices in the society and state. Political parties' open door to the ill-educated and immoral people, they become opportunists and look for return, violating rules and regulations, refuting laws and rights on the power politics supported by party. Prior to the Parliament election, the nomination is often surprised the local party leaders and activists. The leaders of the third world countries turn tyrannical even though they promise to keep up democracy. Democratic approach, aspiration and efforts are usually questioned. Fund for candidates in the election is a big factor in these countries. There are business people to fund the candidates in election.

\begin{tabular}{|c|c|}
\hline Causes & Percentage \\
\hline Failure of political parties & 32 \\
\hline Lack of democratic values & 13 \\
\hline Illiteracy & 12 \\
\hline Imperial conspiracy & 9 \\
\hline Failure of government & 5 \\
\hline Poverty & 5 \\
\hline Intervention of army & 4 \\
\hline Lack of commitment on the part of the parties & 4 \\
\hline Bureaucratic conspiracy & 4 \\
\hline Lust for power & 2 \\
\hline Dependency on foreign aid & 1 \\
\hline Others & 3 \\
\hline Don't know & 6 \\
\hline Total & 100 \\
\hline
\end{tabular}

Table 6: Why could democracy not be established in Bangladesh? ${ }^{16}$

\section{Social Connection of the Political Leaders}

Whatever ill-educated, immoral and greedy leaders are, each of them comes from the community and has some sort of local and external patrons of muscle power and political influence. These grassroot political activists and leaders are having relationship with the central level leaders of the parties, and such relationship is based upon some exchanges of influence, power and resources ${ }^{17}$. Thus the grassroot people are somehow or other connected with the central level leaders via these local level leaders acting as mediators. As a result the basic rights like freedom of speech, right to jobs available locally and rights to justice are subject to political connections, because all central leaders in government and autonomous bodies are heavily politicized ${ }^{18}$. So, the rights due for the common masses in the society, or the rights which they should enjoy being the inhabitants of the society and being the citizens of the state are subject to relation with the leaders and money, consequently good governance are greatly hampered. The local people accuse that these local political activists who have no proper education, honesty, sense of good or bad, and are equipped politically with money and muscle power are causing the rights of general peoples hampered which are clearly guaranteed by the Constitution of Bangladesh. They even don't hesitate to threaten the society ${ }^{19}$.Eventually Judgments goes in favor of who are politically more powerful in the society, refuting truth or falsehood in true terms and good governance becomes affected ${ }^{20}$. In the political arena, defection of political leaders from one party to another and factionalism are widespread in Bangladesh. "Data available on 318 members of parliament in the 7th JS reveals that 65\% (200), MPs were associated and affiliated with a single party from the commencement of their political life, $34 \%$ have altered their political affiliation once and more ${ }^{21}$. . A poll regarding presence of mastans in the party is as follows:

\footnotetext{
${ }^{16}$ Khan, Shamsul I.; Islam, S. Aminul and Haque, M. Imdadul, 2008. Political Culture,Political Parties and the Democratic Transition in Bangladesh

${ }^{17}$ Institutionalization of Democracy in the Political Parties in Bangladesh, Md. Saidur Rahman

${ }_{18}^{18}$ ibid

${ }^{19} \mathrm{ibid}$

${ }^{20}$ ibid

${ }^{21}$ Rashid A.(ed.) (1997), Pramanno Sangsad. Dhaka:Tatthya Seba.
} 


\begin{tabular}{|l|l|}
\hline Responses & Percentage \\
\hline Present & 89 \\
\hline Absent & 5.9 \\
\hline Don't know & 5.1 \\
\hline Total & 100 \\
\hline
\end{tabular}

Table: Presence of mastans (miscreants) in the party ${ }^{22}$

\section{Party Funds and expenditure}

In Bangladesh, political parties nominate the business people in exchange of fund for general election. Being elected to parliament, these businesspeople enjoy opportunity to evade taxes from their business and use their identity to gain more money ${ }^{23}$." These businesses - politicians usually do not have political connections at the grassroots. They often stay away from the constituency mostly in the capital for their own business purpose. They create a separate client channel bypassing the good governance for implementing of the development projects. Even in some cases, these cause clashes among the lobby groups with the parties ${ }^{24}$. The parties depended on the donations of the masses to run its day-to-day activities. Now the parties rely on extortion, donations of enthusiastic criminals looking for favors, and huge nomination fees before the elections. Most of the major political parties do not have a bank account from where its running costs are funded, the party chief's personal account is the party's bank account; it is as feudal as it can get ${ }^{25}$. Money can buy most of the politicians and bureaucrats up to the grassroot level. But mainstream politics of Bangladesh can be labeled as the politics of Money and Muscles.

As evidence of the existence of consent based ruling system in Bangladesh since 1990, it is possible to cite the example of three consecutive parliamentary elections.

\begin{tabular}{|l|l|l|l|}
\hline Occupation & $\mathbf{7}^{\text {th }}$ parliament & $\mathbf{5 t}$ Parliament & $\mathbf{1}^{\text {st }}$ Parliament \\
\hline Businessman & $48 \%$ & $59 \%$ & $24 \%$ \\
\hline Lawyer & $15 \%$ & $19 \%$ & $26 \%$ \\
\hline Professional & $15 \%$ & $19 \%$ & $16 \%$ \\
\hline Politicians & $3 \%$ & $2 \%$ & $12 \%$ \\
\hline Others & $19 \%$ & $5 \%$ & $22 \%$ \\
\hline
\end{tabular}

Occupation of MP,s in $7^{\text {th }}, 5^{\text {th }}$ and $1^{\text {st }}$ Parliament ${ }^{26}$

XV. Intra-party administration and nepotism

For the lack of education, presence of high poverty the social and cultural structures are not favorable to democratization. There is no democracy within the most of the political parties even though the party is elected to from government and the government functions. Either monarchy or dictatorship controlling the party leading position and they are giving illegal opportunity to the favored businessmen to gain black money. As result there the killers can escape trial, the miscreants turn politicians, and money can cover up crimes. Here works a nexus of political patronage. So, the party chief who already has taken the donation is unable to tackle such precarious situation and correct the wrongdoers in the party. Democracy is more urgent in the central tiers of the political parties to ensure good governance ${ }^{27}$.

\begin{tabular}{|l|l|l|}
\hline Extent of prevalence & Regionalism (Respondents in \%) & Nepotism (Respondents in \%) \\
\hline Very widespread & 25 & 32 \\
\hline Widespread & 55 & 51 \\
\hline Not very widespread & 19 & 16 \\
\hline Don't know & 1 & 1 \\
\hline Total & 100 & 100 \\
\hline
\end{tabular}

Table 4: Prevalence of regionalism and nepotism within party ${ }^{28}$

\footnotetext{
${ }^{22}$ Khan, Shamsul I.; Islam, S. Aminul and Haque, M. Imdadul, 2008. Political Culture,Political Parties and the Democratic Transition in Bangladesh

${ }^{23}$ Institutionalization of Democracy in the Political Parties in Bangladesh, Md. Saidur Rahman

${ }^{24}$ ibid

${ }^{25}$ ibid

${ }^{26}$ Transparency International Bangladesh(2003)

${ }^{27}$ Institutionalization of Democracy in the Political Parties in Bangladesh, Md. Saidur Rahman

${ }^{28}$ Khan, Shamsul I.; Islam, S. Aminul and Haque, M. Imdadul, 2008. Political Culture,Political Parties and the Democratic Transition in Bangladesh
} 
As per the table, $55 \%$ of the respondents say regionalism has wide effect in getting posts in the national level committees in political parties, while $25 \%$ say it's very wide. Again, $51 \%$ of the respondents say that nepotism is widely prevalent in getting posts in the committees. The grassroot leaders are hardly found in the party high commands, especially as the party chiefs as a result democracy being seized and familicracy is established, which in nature is dynastic or monarchic ${ }^{29}$. Each major political party is headed by a person who is all-powerful in the administration of the party including the formation of central and executive committee. The party structure and committees are filled by choice and not by election ${ }^{30}$. The elected leaders or members of parliament don't have enough education and skill to assess on their own the merits of laws and policies in the state $^{31}$. That is why they want to attend dialogue on significant national issues or laws raised in the parliament. While asking about how many the elected candidates could contribute to sustain their rights, fulfill needs of the constituencies, and ensure law and order in the society, the respondents critically questioned sense of judgment, values and prudence of their own leader ${ }^{32}$.

\section{Lack of Compromise and Consensus}

The political leaders do not talk of or do not pay attention to the essential and human rights of the citizens. Some respondents critically said that their own elected leaders and law makers are rather engaged in breaking rules, violating laws, threatening good people with their oppressive cadre weapons. In the political arena, conciliation hardly takes place between the parties. The relationship between the ruling party and the opposition is characterized by a high degree of animosity and conflict. The party in power looks upon the opposition with mistrust. Even the opposition is not allowed to ventilate their grievances and opinion in the plenary sessions, which in turn provoke them to stage frequent walkouts or boycott the Parliament, and organize street protests ${ }^{33}$. Switching off the microphone of the leader of the opposition by the speaker is very common in Bangladesh parliament. Debates, criticisms are not welcome and treated as threats to government constancy. History speaks that opposition political parties in Bangladesh is the history of oppression, intimidation and police harassment by the incumbent government. For this reason, opinions against violations of good governance can never be traced in this country.

\section{Hartal (Strike) as a sign of protest}

The cost of Hartals is equivalent to 3-4 percent of GDP ${ }^{34}$. Hartals affect all service, businesses and education sectors. The UNDP report shows 95 percent people believe that Hartals are damaging for economy and society. Due to the scantiness of compromise between the two contending parties in Bangladesh, within two years (1995-96) 173 days hartal was observed by the opposition party causing perpetual upset to the economy and daily life of Bangladesh. Moreover, from 1996 to 2003, more than 100 days hartal was observed by the main opposition party in Bangladesh. According to a press statement given by a former finance minister, one day's hartal incurs an estimated loss of BDT 386 corers (67 million USD) $)^{35 .}$ The 5th, 7th and 8th National Parliament (Jatiya Sangsad) which came into being in free and fair elections have also been rubber stamp in the hand of the ruling party due to the conflict and lack of consensus and compromise between the ruling and the opposition political parties in Bangladesh ${ }^{36}$. It is pertinent to note that the major opposition parties in the parliament have conceded to boycotting the plenary sessions in the 5th, 7th and 8th JSs and calling hartal off and on. National consensus on major national issues i.e.- form of local government, foreign policy, appointment of incumbents in constitutional bodies, effective running of parliament etc. between the ruling party and the major opposition is virtually absent in Bangladesh ${ }^{37}$

\section{Absence of moral philosophy in politics}

History also reveals that commitment of the political class played a vital role in the success of Western liberal democracy in many states like UK, USA, Italy and Germany ${ }^{38}$. During the colonial and military rules democratic political parties and politicians in this region obtained brilliance in the politics of opposition ${ }^{39}$. Political oppositions have continued to use the same method against the party-in-power even after independence.

\footnotetext{
${ }^{29}$ Institutionalization of Democracy in the Political Parties in Bangladesh, Md. Saidur Rahman

${ }^{30}$ Ahmed, M. (1995), Democracy and the Challenge of Development: A Study of Politics and Military Interventions in Bangladesh. Dhaka :

University Press Limited

31 Institutionalization of Democracy in the Political Parties in Bangladesh, Md. Saidur Rahman

32 ibid

33 Ahmed, N. (1997), 'Parliament-Executive Relations in Bangladesh', The Journal of Legislative Studies,3(4):70-91.

${ }^{34}$ (UNDP 2005)

35 (Daily Star September 29, 2003).

${ }^{36}$ Democracy in Bangladesh, Shantanu Majumder, Assistant Professor, Department of Political Science, University of Dhaka

${ }^{37}$ ibid

${ }^{38}$ (Almond \& Verba 1963: 483)

${ }^{39}$ Democracy in Bangladesh, Shantanu Majumder, Assistant Professor, Department of Political Science, University of Dhaka
} 
Again, the ruling party has failed to show due respect to the opposition, which makes the moderate democracy virtually unsuccessful. As a result of this failure from both sides, today the Bangladeshi version of democracy means merely a fight for state power. And the rules of the game of liberal democracy have barely been practiced $^{40}$.

\begin{tabular}{|l|l|l|l|}
\hline & $\mathbf{7}^{\text {th }} \mathbf{J S}(\mathbf{1 9 9 6 - 2 0 0 1 )}$ & $\mathbf{5}^{\text {th }} \mathbf{J S}(\mathbf{1 9 9 1 - 1 9 9 6 )}$ & $\mathbf{1}^{\text {st }} \mathbf{J S}(\mathbf{1 9 7 2 - 1 9 7 5 )}$ \\
\hline Post Graduate & $40 \%$ & $38 \%$ & $28 \%$ \\
\hline Graduate & $45 \%$ & $46 \%$ & $45 \%$ \\
\hline Under Graduate & $15 \%$ & $16 \%$ & $27 \%$ \\
\hline
\end{tabular}

Educational Background of Mp's of $1^{\text {st }}, 5^{\text {nd }}$ and $7^{\text {th }}$ parliament ${ }^{41}$

\section{Impetus behind political malefactors}

Both vertical and horizontal 'patron-client relationship' have been practiced within the major political parties of Bangladesh, which have contributed to the decay of one of the basics of any political parties, i.e., offering service to the people ${ }^{42}$. In exercising vertical patron-clientilism, the political parties develop a hierarchic system of leaders and cadres from centre to the grass root level. Student Wings and Youth Wings i.e. Chattra League/Chattra Dal, Jubo League/ Dal, Krishok League/Dal etc ${ }^{43}$.

\section{Causes of the failure of political parties}

Again political parties as institutions are grounded in historically emergent cultural patterns and social structure. The way political parties behave is greatly influenced by cultural and social factors. Sociologist Alex Inkles and Psychologist Daniel Levinson identified three basic issues in the society which count in functioning of societies, of groups within the societies, and of individuals within those groups. The issues are:

- $\quad$ Relation to authority

- Conception of self - in particular, the relationship between individual and society - and the individual's concept of masculinity and femininity

- Ways of dealing with conflicts, including the control of aggression and the expression of feelings

Power is centralized in a few hands. Subordinates expect to be told what to do. There are a lot of supervisory personnel, structured into tall hierarchies of people reporting to each other. Superiors are entitled to privileges. Inequality among people, respect system, authoritarian values, obedience, dependence, and hierarchy, centralization of power, autocracy, charisma and tradition based power, and the privileged powerful etc ${ }^{44}$. Indicators of power distance of society are as follows:

- Participation and pressure of the powerful, moneyed and elite people in the political party;

- Party being loyal to clients and guard of their interests;

- Party principles are being overlooked;

- Party leader being not elected by the party leaders;

- Most party decisions not taken by committees, rather by party leader;

- Choices of the party leaders being not challenged;

- Family members of party leader become next leader;

\begin{tabular}{|c|c|}
\hline Causes of failure & Percentage \\
\hline Absence of leaders with high ideals & 55 \\
\hline Lack of well-conceived programs & 14 \\
\hline Internal conflict & 9 \\
\hline Absence of honest and dedicated workers & 8 \\
\hline Others & $\ldots$. (other minor percentages are omitted) \\
\hline
\end{tabular}

Table 5: Causes of parties' failure to sustain democracy ${ }^{45}$

\footnotetext{
40 supra

${ }^{41}$ Transparency International Bangladesh(2003)

42 Islam, S Aminul. "Political Parties and the Future of Democracy in Bangladesh." In Bangladesh on the Threshold of the Twenty-First

Century, edited by A. M. Chowdhury and Fakrul Alam. Dhaka: Asiatic Society of Bangladesh, 2002.

${ }^{43}$ Institutionalization of Democracy in the Political Parties in Bangladesh, Md. Saidur Rahman

${ }^{44}$ ibid

${ }^{45}$ Khan, Shamsul I.; Islam, S. Aminul and Haque, M. Imdadul, 2008. Political Culture,Political Parties and the Democratic Transition in Bangladesh
} 
Because of lack of ideals in the top or central level party leaders, they themselves do not practice democratic principles in the party activities, which demoralize the other grassroot level party leaders in maintaining democratic orders and principles. On the other hand, absence of well-meaning, well-defined programs, cannot also bind the party activists in order and in principle ${ }^{46}$.

\section{Mechanism for the effectiveness of political party}

The above mentioned tasks and functions need to be performed and executed in a functional democracy. The political parties and citizens need to follow some rights and obligation guaranteed by the constitution or by law: freedom of association ${ }^{47}$; freedom to stand for election ${ }^{48}$; provision for fair and peaceful competition $^{49}$; freedom of speech and assembly ${ }^{50}$; mechanism of plurality; inclusion in the electoral process; a level playing field and freedom from discrimination ${ }^{51}$; media access and fair reporting ${ }^{52}$; transparent and accountable political finance. There are number of obstacles on the way to establishing democracy in the country. The political parties need to be institutionalized first. Otherwise, the people cannot expect good governance if the party comes to power. Since independence, no political party, big or small, has been practicing democracy within itself.

\section{Evaluation}

In the developed country we see parallel and non-disturbing procedure of governance which is the fruit of clean practice of democracy within party. But Bangladesh as a developing country is far to reach and suffering lack of good governance and all of my analysis proves and emphasizes improper democratic practice of political party. Structural and super structural development and strong political platform and all of the possibilities to be developed are disturbed by political parties' malpractice and leads bad governance in Bangladesh.

\section{Conclusion}

To establish good governance and democracy, there is no way to refresh the political party's wrongdoings. Democracy and good governance are synonymous. To nurture democracy in the state the political parties have to practice democracy within the political parties and they need to be institutionalized first. Otherwise, the people cannot expect good governance if the party comes to power. There is no alternative to ensure the institutionalization of democracy within party because it is the gear of the whole democratic system. We should pay attention to make such type of democratic platform on the hands of political party to ensure good governance because it is the easiest way to fulfill our long cherish desire to be flourished as a proud nation.

\footnotetext{
${ }^{46}$ Democracy in Bangladesh, Shantanu Majumder, Assistant Professor, Department of Political Science, University of Dhaka

${ }^{47}$ Article 38, Bangladesh Constitution

${ }^{48}$ Article 66, Bangladesh Constitution

${ }^{49}$ Articles 29 \& 38, Bangladesh Constitution

${ }^{50}$ Article 37, Bangladesh Constitution

${ }^{51}$ Article 27, Bangladesh Constitution

${ }^{52}$ Article 39, Bangladesh Constitution
} 